\title{
Economic Potentiality And Consequences Of Inflation In Argentina
}

Gbolahan S. Osho, Prairie View A\&M University, USA

Matthew Uwakonye Grambling State University, USA

\begin{abstract}
This paper provides insight on Argentina's crisis since the default in an attempt to find a way out of the economic crisis. In 1991 Argentina pegged its peso to the U.S. dollar to stabilize the economic conditions and it set in restrictions on the issuance of money to control hyperinflation. The problem faced by Argentina has come from what will be termed "econogenocide," that is, killing one's own economy through its own acts, procedures, policies, and reforms. However, there are more signs that the economy is over the worst. An examination of the policies and procedures that caused the downfall of this nation's once thriving economy can show the tell-tale signs that other nations may need to watch out for, and protect against.
\end{abstract}

\section{INTRODUCTION}

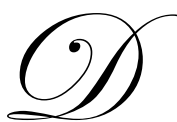

uring the period of 1990-2004, Argentina has seen the value of its currency, the Argentine peso, drop dramatically. Hand-in-hand with this devaluation of the peso has been the astronomical inflation rate associated with the currency. This extremely high inflation rate can be described as "hyperinflation."

Argentina faced an inflation rate nearing $70 \%$ last year, with minimal signs of a comeback this year. Coupled with the hyperinflation is the economic contraction that has occurred, rivaling the economic contraction of the United States during the Great Depression. This is all in spite of the reputation Argentina had earned as a strong model for economic stability during the 1990's. The price of the peso was pegged to the price of the U.S. dollar in exchange rates for approximately an entire decade prior to this alarming occurrence. The reform that equalized the dollar and the peso was enacted following a similar pattern of hyperinflation that ended in the late 1980's. But, since then, economists were eager to model other countries' economies to Argentina's, until now.

The problem facing Argentina has come from what will be termed "Econogenocide," that is, killing one's own economy though it's own acts, procedures, policies, and reforms. It is evident that Argentina is guilty of this, even though they were not meaning for it to happen. However, through careful examination, one begins to wonder why the country didn't see this coming. If they did see it in the future, why didn't they begin to create measures to counter what was about to happen?

Currently, the nation is in a state of shock. Banks have been holding on to the monies the invested in them, without allowing the consumers access to them. President after President is being ushered into the top-ranking position of the country in hopes of stabilizing the economy through leadership and reforms. Other countries are finding it difficult to invest in the falling nation. The citizens are scared, as well. The state of the Argentinean economy is not looking good. Hence the goal of the research paper is to analyze the economic implications of the inflation in Argentina with specificity to determine the causes of the problems that led to the collapse of the economy of Argentina with the period of 1990-2004. It will evaluate the impact on the Argentinean economy, based on the steps they have taken to correct their unfortunate situation. This paper will provide recommendations to other countries that may someday face a similar set of circumstances on how to avoid this in the future. Through these objectives, an in-depth of analysis of the hyperinflation and the failing of the Argentinean economy will be presented. 


\section{MODEL SPECIFICATION}

Models of inflation relating volatility in inflation to inflation expectations is used with the expectation indicator models is relatively short. The rationale is that the inflation rate this quarter will be influenced by what firms and households expect the inflation rate to be over the same period. Trend inflation could instead be measured with long-term inflation expectations. Long-term expectations are a direct measure of trend inflation in statistical models of the economy. This model of inflation with lagged variables provides a useful starting point for assessing changes in the behavior of inflation.

$U_{t}-U_{t}^{b}=\alpha_{1}\left(U_{t-1}-U_{t-1}^{b}\right)+\alpha_{2}\left(U_{t-2}-U_{t-2}^{b}\right)+b_{t}$

Where $U_{t}$ is denoting core PCE inflation, $U_{t}^{b}$ is denoting trend inflation measured as the long-term expectation. $\alpha_{1}, \alpha_{2}$ are the model coefficients which can be used to determine current inflation from the past values of inflation and inflation expectations. $b_{t}$ is the regression error which captures unexpected changes in detrended inflation and represents the shocks to inflation. If we the left term into the right we can get:

$U_{t}=\alpha_{1} U_{t-1}+\alpha_{2} U_{t-2}-\alpha_{1} U_{t-1}^{b}-\alpha_{2} U_{t-2}^{b}+b_{t}+U_{t}^{b}$

If we suppose the moment that inflation expectations move slowly, such that inflation expectations in the past two periods are roughly the same as in the current period. Then the formula can be changed into:

$U_{t}=\alpha_{1} U_{t-1}+\alpha_{2} U_{t-2}+\left(1-\alpha_{1}-\alpha_{2}\right) U_{t}^{b}+b_{t}$

Which means suppose the $U_{t-1}^{b}=U_{t-2}^{b}=U_{t}^{b}$ we use $U_{t}^{b}$ to replace the other two terms. From above, a large coefficient on inflation expectations implies expectations exert a significant influence on inflation. A large coefficient on inflation expectations translates into a small value of $\alpha_{1}+\alpha_{2}$, smaller coefficients $\alpha_{1}$ and $\alpha_{2}$ imply a greater influence on long-term expectations on inflation has become more influenced by inflation expectations. Changed in model coefficients could also explain the reduced volatility of inflation in recent years. Alternatively, reduced volatility could be due to a fall in the size of the shocks to inflation. The model is a vector auto regression with time-varying coefficients and stochastic volatility. The model takes the form:

$\alpha_{t}=\delta_{1, t} \alpha_{t-1}+\delta_{2, t} \alpha_{t-2}+\varphi_{t}^{-1} \gamma_{t}^{5} \mu_{t}, \quad \operatorname{var}\left(\mu_{t}\right)=I$

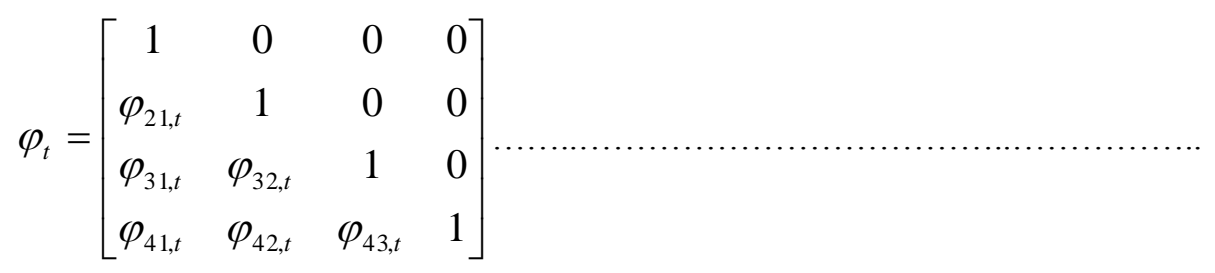

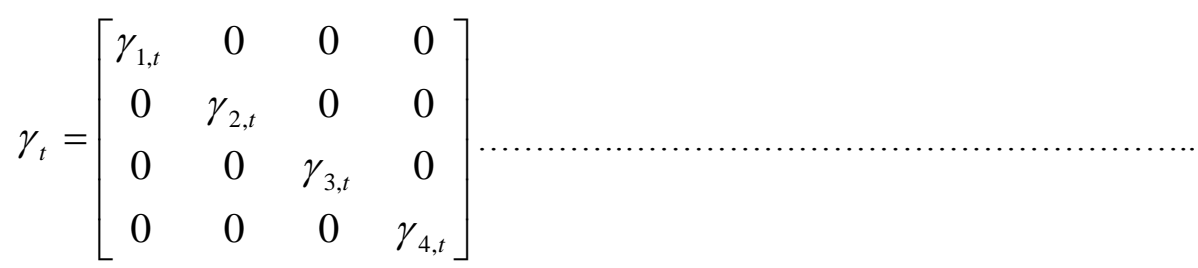


The errors $\mu_{t}$ are independent structural shocks, identified from the common recursive, ordering, the reduced-form residuals are $\varphi_{t}^{-1} \gamma_{t}^{5} \mu_{t}$ with all the coefficients of $\delta_{1, t}$ and $\delta_{2, t}$ Stacked in a vector $\beta_{t}$ the model can be written as:

$\alpha_{t}=\beta_{t} \delta_{t}+\varphi_{t}^{-1} \gamma_{t}^{5} \mu_{t}$

Where $\beta_{t}$ is a stacked vector containing all of the right-hand-side variables for all equations. The time variation of the model parameters is governed by the following equations:

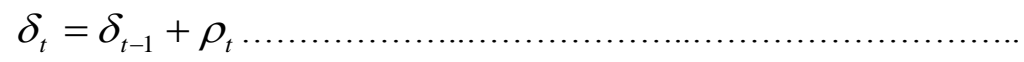

$\varphi_{t}=\varphi_{t-1}+\sigma_{t}$

$\log g \gamma_{t}=\log \gamma_{t-1}+m_{t}$

\section{CAUSES OF THE COLLAPSE OF THE ARGENTINEAN ECONOMY}

Argentina's current economic tribulations cannot be limited to one or two causes. However, there are some definite reasons that we can review that led to the collapse of the economy. Argentina experienced a fallen economy in the 1970's and 1980's, and thus began numerous reforms to restore its economy, many of them contributing to the Econ-Genocide. Argentina followed suit to other nations, including Chile, Mexico and Southeast Asia by changing to an economy that encouraged foreign trade and investments and privatized state-owned industries, from an isolated and state dominated economy, according to Martin Feldstein. This move was an attempt to raise the level of trade and increase the demand for the peso, ultimately an attempt to appreciate the peso. But, Argentina went a step further than other countries by pegging the peso at a one peso to one-dollar exchange rate, and mandated that those with pesos could convert them to dollars freely, if they desired. This mandate was backed by the currency board system (Argentina's central bank).

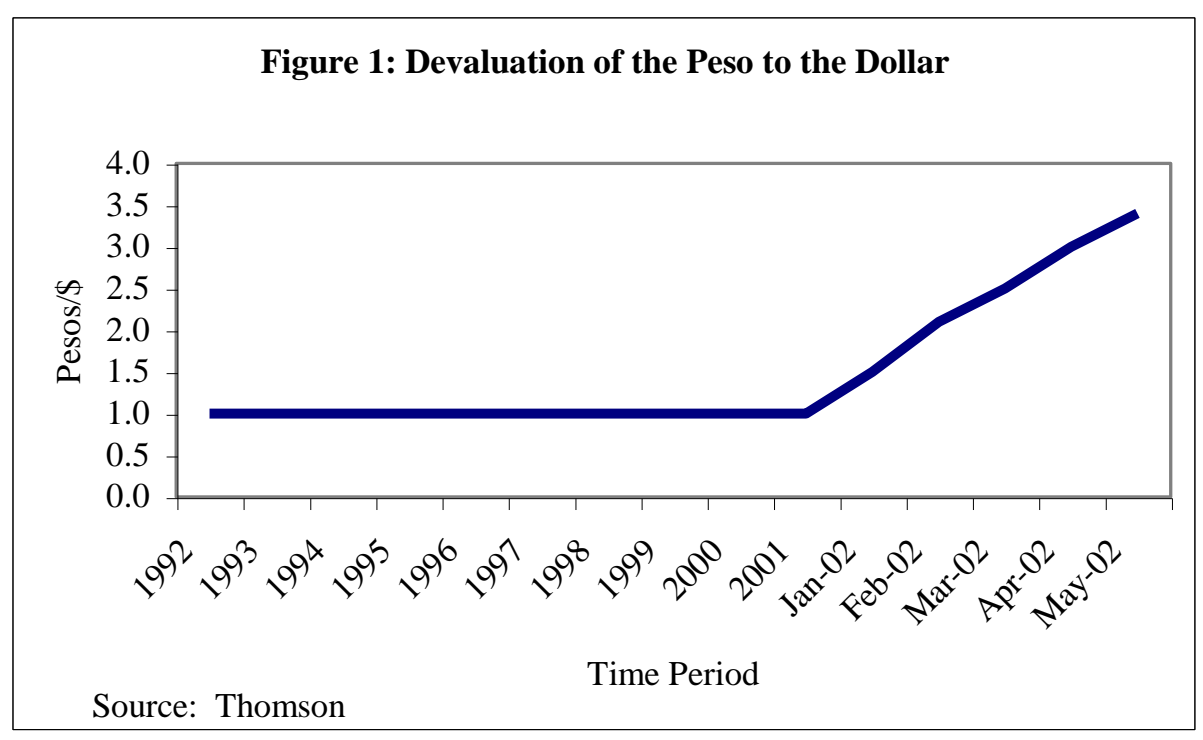


Argentina had a plan, new President Carlos Menem, and Prime Minister Domingo Cavallo. The only thing Argentina now needed was strong economic growth. The country needed to generate earnings on its foreign exchange to pay its mounting international debt, requiring them to generate more exports than imports (Feldstein 2002). Unfortunately, the one-to-one peg hurt Argentina because it made their products uncompetitively expensive compared with those abroad. Argentina needed production to increase faster than wages, which would have allowed the prices of Argentine goods to decline relative to those abroad (Feldstein 2002). It did not happen because the further reduction in production costs that Argentina need to be competitive worldwide was prevented by labor laws and strong union pressures.

Argentina was now stuck. The mandate that all pesos were to be backed by a U.S. dollar made it so that Argentina could not create more pesos without the backing; but the one-to-one convertibility law prevented the adjustment necessary to lower the level of the current-account deficit. The peso grew in strength and Argentina's competitiveness worldwide declined as the dollar grew in strength against other currencies. The dollar rose quickly against the Japanese yen in the mid 1990's, against the currencies of south East Asia a couple years later, and against the European currencies as the European Union's foundation was being late in the late 1990's. Terms of trade were also working against Argentina, as the prices of the products imported by Argentina were higher than the prices of the products exported by the country. When the real, Brazil's currency, fell in 1999, Argentina was dealt with the most punishing blow. (Feldstein 2002)

The inevitable result was increasing current accounts deficits, which reached nearly five percent of GDP, creating foreign debt. Low private savings rates, which reduced Argentina's source of investments, and deficits in the budgets of the central and provincial governments, were also evident in the examination of Argentina's foreign debt growth. (Moreno 2002) Argentina failed in controlling government spending and tax evasion, especially in the provincial levels. A constitutional law requiring revenue sharing by turning any gain in tax revenue acquired by the central system into an extra source of funding for provincial spending was not enough to curtail the provincial deficits. In addition, as the debt mounted, the interest rate that Argentina was forced to pay foreign creditors rose, further increasing the annual imbalance and accelerating the growth of the foreign debt. (Moreno 2002) Default became unavoidable.

Knowledgeable Argentines and foreign investors knew that the peso must be devalued to reduce current accounts deficits without a massive recession. The convertibility law allowed consumers to shift pesos into dollars, and then take the dollars out of the country (Feldstein, 2002) increasing the need to devalue the peso. Argentina acquired a loan from the International Monetary Fund (IMF) in 2001 that gave a temporary boost, but in January 2002 the peso greatly devalued.

The question most would ask is "Why did Argentina not devalue the peso sooner, rather than wait until the default was necessary?" Moreno explained the resistance the Argentine Government had in devaluating the peso. First, was the fear that breaking the one-to-one peg and devaluing the peso would bring back high inflation that had previously rendered the economy worthless before the two currencies were inter-linked? Second, because there are so much dollar-denominated debt amongst the households and businesses in Argentina, the government anticipated that peso devaluation would create havoc, prompting widespread bankruptcies and defaults because they would be essentially raising the peso value of outstanding debts. This problem would affect the central and provincial governments as well, which possessed a great amount of dollar-denominated debt owed to foreign creditors, which would be more cumbersome after the devaluation, since tax revenue was collected in the devalued pesos. Lastly, there was always hope that the situation would just eventually improve, given some time. The large U.S. trade deficit created hope that the dollar might decline sharply relative to the yen and the European currencies, making Argentine products much more competitive internationally. But, it did not happen. In fact, the dollar (and therefore the peso) continued to strengthen in 2000 and 2001 (Feldstein, 2002).

\section{CURRENT ARGENTINEAN ECONOMY}

Despite the recent continuing short-comings by this struggling nation, there seems to be hope. The future is starting to look a bit brighter. In a release to Bloomberg news on July 3, 2003, Central Bank President and former head of emerging market research at J.P. Morgan Chase \& Company, Alfonso Prat-Gay, said that the outlook is 
good for the country for the second half of 2003. He believes that even without any growth the last quarter of the year, the economy will expand to 4.8 percent. He anticipates the economy could grow to an even higher rate of 5.9 percent, which is more than the 4 percent the IMF anticipates. The economy has already shown sign of growth, growing 5.4 percent in the first quarter of this year. Prat-Gay noted in a Senate hearing the morning of the release that there is a recovery of internal demand and in consumption, and that demand for money is much higher, a welcome sign among the citizens and consumers of Argentina. The latest proof of this expansion was provided through a June automobile sales report. The sales were doubled that of the same period last year, and up 14.4 percent from the month of May.

Prat-Gay also commented on the expected inflation of the Argentine economy, a problem that has haunted the country for the last couple of years. "I don't see a risk of inflation..." (www.bloomberg.com, 2003) He said that he expects the inflation rate to be at the lower end of the five percent to fifteen percent range-a range that is not great for most economies, but surely a sign of improvement in Argentina. In fact, the inflation rate dropped slightly in the month of June, with consumer prices decreasing 1 percent, dropping for the second straight month. The currency has increased in value of 20 percent this year, following the decline in about two-thirds of its value in 2002. In addition, of the 59 currencies tracked by Bloomberg, Argentina's peso was the third highest performing. Despite these promising signs, Argentina still faces some serious challenges - primarily with unemployment. PratGay said that the economy needs to "...grow faster...We still have an unemployment problem and to get rid of the problem, we need to grow faster" (www.bloomberg.com, 2003).

Others within the circle of policy makers in the Argentina economy are also eager to applaud the recent efforts to correct the serious situation at hand. In an article entitled, In Argentina, "No Turning Back the Clock," posted in July 17, 2003 on the Business Week website, Roberto Lavagna, Argentina's Economy Minister since April 2002 and former Argentine ambassador to the European Union detailed his accounts of resurgence in the Argentine economy. When asked why critics of Argentine President Kirchner saw the new reforms as just shots in the dark, with out having any kind of laid out program, Lavagna insisted that the critics were "mistaken." He noted that President Kirchner took office vowing to continue the policies that Lavagna, himself, initiated. He said that the problem is derived from people who mistake Argentina's economic program with their own interests. Managing an economy requires more than accommodating bankers and businessmen. The workers and consumers must also be kept in mind. Lavagna was quick to pat himself on the back by mentioning the approval of a $25 \%$ increase in minimum wage, a move designed to help the poorest people maintain their purchasing power despite the high inflation. In addition, they also completely eliminated controls on the exchange market and freed up assets that were frozen in the banking system. Most important, the Argentine policy makers re-unified the currencies of Argentina by buying back more than $\$ 2.5$ billion (in U.S. dollars) worth of currencies used within the provinces of Argentina to pay debts during the hyperinflation period. It is evident that he and the other policy-makers are very proud of the initiatives they have taken.

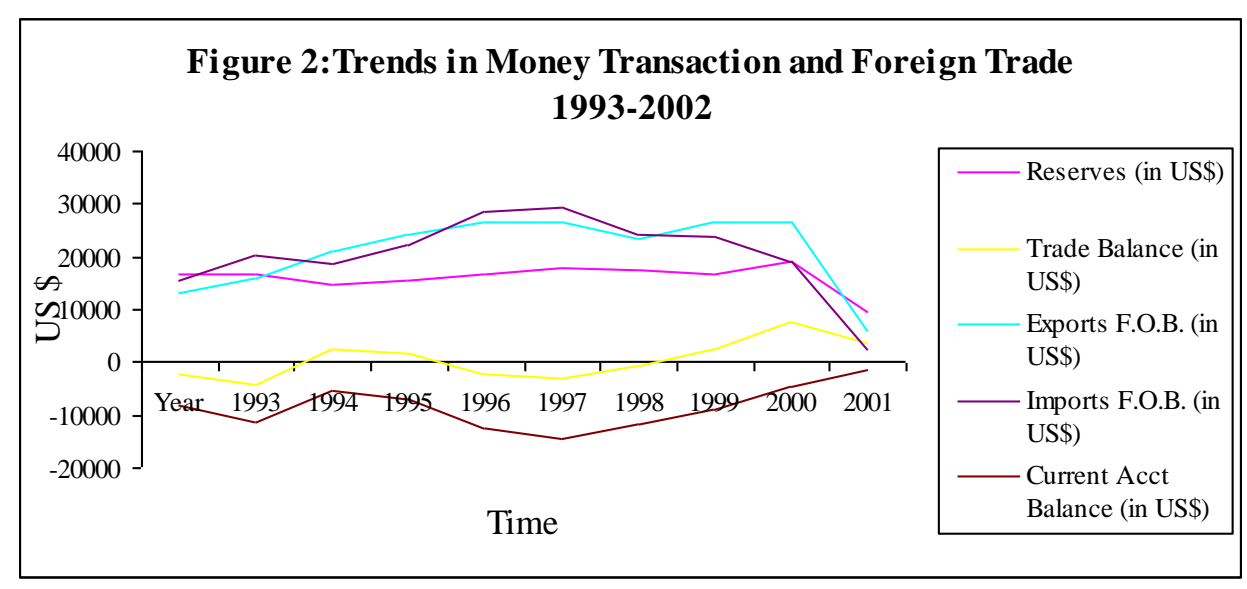


Lavagna also went into detail about the give-and-take that happen when instituting economical regulations. The government and currency board must consider many different affected parties. The consumers must be allowed to earn and spend the money they need to live their lives. The private business sector must be allowed to run and function to its full capacity to pump money into the hurting economy. In addition, the banks must also be taken into consideration, as they are the ones who have the power to hold, borrow, and lend money. He indicated the difficulty that the policy-makers have had in the past balancing the needs of everybody affected, but in nearly the same breath, applauded the recovery advancements that have been made under President Kirchner's system.

The last vote of confidence by Lavagna was given at nearly the end of his interview. Keeping right in line with Prat-Gay's comments hailing the sheer number accomplished by the Argentine's this year, Lavagna said that consumer confidence remains at its highest levels in the last five years. Industrial production fell month by month the last two months, but on an annual basis, it continues to grow faster than GDP. This shows mixed signals, but the important thing is that Argentina's growth projections for the year remain around 4.5\%, which is sufficient, according to Lavagna, for them to meet their target of a $2.5 \%$ primary fiscal surplus.

It is quite evident through extensive research into Argentina's economic crisis and recovery that there are very few critics of the reforms currently enacted by the policy-makers. This must mean that they have done a great job in turning everything around. The citizens, the business people, the banks, and other countries must all be very pleased with what they are witnessing. The numbers for the past year have looked good, and the projections for the rest of this year look even better. The question then remains, does this make that everybody is happy? Are all of those with vested interest in the Argentina economy now satisfied, or at least comforted by the improvements made in the economy?

The answer seems to be 'no,' and the biggest critic of them all seems to be the group with the most at stake (the IMF). This has given Argentina some criticism to dish out. An article posted on www.reuters.com, on July 2, 2003, details why they think the IMF is attempting to sever ties with the Argentineans. Argentina accused a sector of the IMF of attempting to sabotage ties after a report was issued that the fund wanted new debt included in the restructuring of the Argentina economy. "A sector within the bureaucratic structure of the IMF is working through the press to sabotage the (lender's) relationship with Argentina," Finance Secretary Guillermo Nielsen said at a ceremony at the Buenos Aires stock exchange. Argentina is struggling to re-strengthen its ties to the IMF after its relations were strained due to the disastrous happening in the past couple of years. This is not the vote of confidence Argentina needed from the IMF. In fact, it flies in the face of everything Argentina is trying to accomplish.

Table 1: Argentina Economic Index 1993 - 2002

\begin{tabular}{lccccccccc}
\hline & $\mathbf{1 9 9 9}$ & $\mathbf{2 0 0 0}$ & $\mathbf{2 0 0 1}$ & $\mathbf{2 0 0 2}$ & $\mathbf{2 0 0 3}$ & $\mathbf{2 0 0 4}$ & $\mathbf{2 0 0 5}$ & $\mathbf{2 0 0 6}$ & $\mathbf{2 0 0 7}$ \\
\hline GDP $^{1}$ & 250,308 & 243,186 & 256,626 & 277,441 & 288,123 & 278,369 & 276,173 & 263,997 & 217,067 \\
Unemployment2 $^{1}$ & 11.5 & 17.5 & 17.2 & 14.9 & 12.9 & 14.3 & 15.1 & 17.4 & 21.5 \\
CPI $^{2}$ & 147.49 & 152.47 & 152.71 & 153.52 & 154.94 & 153.13 & 151.69 & 150.08 & 193.5 \\
CPI \% $_{\text {Real Wages }}^{3}$ & 3.36 & 3.38 & 0.16 & 0.53 & 0.92 & -1.17 & -0.94 & $-1.07 \%$ & 30.5 \\
GDI3 & 931 & 909 & 893 & 876 & 879 & 902 & 916 & 914 & 716 \\
Exchange Rate $^{4}$ & 44,325 & 44,528 & 48,484 & 57,047 & 60,781 & 53,116 & 49,502 & 41,650 & 41,750 \\
& 1 & 1 & 1 & 1 & 1 & 1 & 1 & 1 & 3.65 \\
\hline
\end{tabular}

1. GDP Market Prices of 1993 Pesos)

2. CPI $(1991=100)$

3. (in 1999 pesos)

4. (Pesos to Dollar)

\section{IMPACT OF ARGENTINEAN CRISIS ON OTHER COUNTRIES}

The disorder in Argentina has now spilled over the country's borders and has caused serious problems in the economy. Among other issues, Argentina's debt default and currency devaluation have increased pressure on Uruguay's currency, causing a severe (about $80 \%$ ) decline in foreign reserves as the central bank attempted to 
defend the currency (Uruguay now has moved to a flexible exchange rate system). No doubt, Uruguay is the country that is suffering most from the disasters in Argentina. In 2002 Uruguay entered its fourth year of recession. Economic troubles in neighboring Argentina caused a staggering 90\% drop in tourists, devastating Uruguay's important tourism industry. The severe crisis in Argentina, the worst in the country's history--which has doubled the poverty index in less than a year to around 50 percent of the population--has crossed the borders despite predictions to the contrary by the IMF. Hence, the feared "domino effect" already has struck the weakened economy in Uruguay, which is extremely dependent on all that occurs in economic and financial affairs other side of the Rio de la Plata. Uruguay deserted its currency peg and floated its peso, which quickly fell (Economist, Jun. 24 ${ }^{\text {th }} 2002$ ).

Simultaneously, it makes a threat to Brazil with an unbalanced economic volatility. Brazil, the largest economy in Latin America, has also seen its currency fall, and the cost of servicing its foreign debts has soared. The crisis has also been clearly felt in Paraguay another member of the Common Market of the South (MERCOSUR). The economic effect of Argentina's crisis will have will definitely have a negative affect on Brazil, but just how negative depends on whether MERCOSUR survives. Furthermore, the Argentine crisis undoubtedly has reinforced the forces of leftist groups, and anti-Americanism throughout Latin America, with an indirect affect on trade, investment, and political cooperation with the United States. President Hugo Chavez, of Venezuela, is currently the most leading supporter of these forces. Ecuador's Finance Minister resigned as a result of a possible scandal in finding its own fraudulent troubles more difficult to handle due to tenseness in the region as a whole. The Argentinean crisis has also reached Mexico where the mood has changed with comments made by the Mexican finance minister, which produced a minor panic in the markets. Francisco Gil Diaz made arguments to congress to move towards organizing public finances. To make his point clear he compared Mexico to Argentina, and its unsuccessful attempt to undertake its public finances. Mr. Gil Diaz used an association to pressure Congress, but his comments had much wider effects. Having no choice in the alarming matter President Vicente Fox, issued a statement saying the Mexican economy was "solid". (Economist, 2002) Argentines are saddened by the downfall of the economy, and have pointed the finger to the outside world for not coming to their rescued sooner. However, the International Monetary Fund (IMF) went to Buenos Aires but had no comment as to how or if they had a plan to help the Argentinean economy. (Economist, 2002)

\section{THE EFFECT MERCOSUR}

The Mercosur created by Argentina, Brazil, Paraguay and Uruguay in March 1991 with the signing of the Treaty of Asuncion, is third largest common market after the European Union and NAFTA. It is recently experiencing economic instability through a financial banking crisis and economic turmoil that Argentina is undergoing, which has had effects on its members. The purpose of Mercosur was to establish a common market, which would allow free movement of goods, services and other productions. It would eliminate non-tariff restrictions and custom duties. Its members agreed to a common tariff and adopt a trade policy. However, Brazil and Argentina the two largest economies have been disputing over antidumping restrictions. Hence, these two presidents have since said they would make efforts toward the formation of a common parliament for the bloc, and reaffirmed a goal to initiate a common currency. But political instability and constant economic crises in Argentina, Brazil and Uruguay have weakened the bloc's structure. Talk of creating a common currency and improving macroeconomic of Mercosur has been going on for years, but few steps have been taken into action.

\section{UNEMPLOYMENT}

Argentina's unemployment currently stands at $18.4 \%$ which is the highest ever seen historically. This means that almost 3.2 million people who are in good condition to work are currently unemployed, in a country of 36 million people. Half of people currently employed have salary averages of approximately $\$ 55$ a month. The unemployment in Uruguay increased by 19\% during the period of July 2002 through September 2002 and was affected several sectors, but increased mainly in Montevideo, the country's capital, which is where half of the country's population lives. Uruguay has been in a recession since about four years. But the situation became worse when Argentina economy collapsed; hence it affected commerce and tourism.

In 2004, the amount of women unemployed increased by $3 \%$ in Montevideo, and $6 \%$ over the rest of the country's workforce. Overall the male unemployment stayed relatively the same. The ones that have had greater 
difficulties in obtaining employment is the younger generation. In effect, the rate of unemployment for the Montevideans of both sexes less than 25 years during the quarter cited was 33.2\%, contrasted to the $10 \%$ unemployment level of those greater than 25 years old. In the remainder of the country, the rate of unemployment of those younger than 25 was about $29 \%$ and the rate of those over 25 years was $11 \%$.

The growing rate of unemployment in Brazil, standing at 1.6 million workers or nearly 19 percent of the working population - has led to an increase in those seeking to go into business. The Brazilian Service in Support of Small Businesses (SEBRAE) reports that, in the first three months of this year, the number of people asking for help in starting their own business increased by nearly 38 percent over the same period last year. However, a person who decides to start a business usually does not understand the amount of time that it will take to recover their original investment. According to SEBRAE, new businesspersons often do not change their lifestyle, and when the money runs out, they panic and close the shop. This is main reason why 70 percent of new businesses close within their first year of operation. In addition, they face another problem in the lack of access to technology, making it difficult for new entrepreneurs to maintain competitive prices and quality in markets that are increasingly open to international competition.

\section{POLICY SHIFT AND RECOMMENDATIONS}

What lessons can others learn from the Argentina's experience? Although there are more, three lessons emerge because of their importance and impact on the country. First, it was a bad idea to try to maintain an exchange rate within such a narrow band. They should have remembered the collapse of Bretton-Woods Agreement, in which the United States pegged its dollar to gold, and other countries pegged currencies to the dollar. When a currency is pegged to another currency, problems arise when one of the countries is experiencing economic turmoil. In this case, since Argentina's law declare that their peso must be exchanged one-to-one with the dollar, they had no room to negotiate interest rates, currency valuation, spot rates with other currencies, and several other important factors needed to maintain a stable economy. Argentina was trying to rely on the stability of another country in maintaining its own stability. In fact, Argentina was in a group of South American countries devoting themselves to the currency-to-dollar conversion peg. Countries who define specific measures to exchange currencies with each other work well, but only when all of them are in 100\% agreement to the policy. Some of these countries decided that this peg was not for them. It is evident that fixed exchange rates lead to currency valuation problems. It did not work this time, and will not work again. Furthermore, pegs are particularly susceptible to political outcomes and external surprises which affect investor's expectations.

Second, Argentina borrowed excessively, and its foreign debt increased tremendously, but they did not enough have dollars in the Central Bank. They imported more than they exported, causing an imbalance of trade. A country must maintain a solid import/export (trade) balance if it desires to function well in the world economy, while maintaining the value of its currency. If one is importing much more than exporting, and they do not have enough money in reserve, they will eventually be close to running out. This is a problem. A country must then print more money to keep a healthy supply within the country, but Argentina was again restricted in doing so by the oneto-one peg of the peso to the dollar.

Finally, the decision to privatize many of Argentina's state-owned firms caused an unstable situation because, through privatization, the government lost a large amount of tax revenue. Governments primarily rely on tax revenue to run a country in a healthy manner, but these monies were not available to the hurting country when they needed them the most. It is clear that Argentina was committing "econogenocide" through its reforms, acts and procedures, meaning that they contributed to their own economic down-fall through these acts. Countries that are beginning to face the beginnings of the same problems must closely examine their economic activities, primarily

keeping in mind the three above-mentioned ideas. This should help them evaluate their processes and practices to determine the proper steps in overcoming a potentially disastrous situation.

\section{REFERENCES}

1. Cibils, Alan B., Kar, Debayani, Weisbrot, Mark. Argentina Since Default: The IMF and the Depression. September 3, 2002 
2. $\quad$ Feldstein, Martin. “Argentina's Fall.” Business Source Premier.” Mar/Apr. 2002. Vol. 81, Issue 2

3. International Monetary Fund: Argentina's Structural Reforms of the 1990s March 2000, Volume 37, Number 1, Pedro Pou

4. Moreno, Ramon. "Learning From Argentina's Crisis." FRBSF Newsletter. Oct. 18, 2002. Number 200231

5. International Monetary Fund: Argentina's Structural Reforms of the 1990s March 2000, Volume 37, Number 1, Pedro Pou

6. http://europa.eu.int/comm/external_relations/mercosur/intro/

7. http://quote.bloomberg.com/apps/news?pid=10000086\&sid=a9E6pmnH9fLc\&refer=latin_america

8. http://www.businessweek.com/bwdaily/dnflash/jul2003/nf20030717_2868_PG2_db053.htm

9. http://www.cia.gov/cia/publications/factbook/fields/2116.html

10. http://www.reuters.com/newsArticle.jhtml?type=topNews\&storyID=3029281

11. http://www.csis.org/americas/sa/scwatch_020108.htm

12. http://www.economist.com/agenda/displaystory.cfm?story_id=1199286 


\section{NOTES}

